\title{
Leaching of Chromium, Copper, and Arsenic from CCA-Treated Utility Poles
}

\author{
Cynthia A. Coles, ${ }^{1}$ Joseph A. Arisi, ${ }^{2}$ Marion Organ, ${ }^{3}$ and Geoff I. Veinott ${ }^{4}$ \\ ${ }^{1}$ Department of Civil Engineering, Memorial University of Newfoundland, St. John's, NL, Canada A1B 3X5 \\ ${ }^{2}$ Edmonton, Alberta, Canada \\ ${ }^{3}$ Nalcor Energy, Lower Churchill Project, St. John's, NL, Canada A1B 0C9 \\ ${ }^{4}$ Science Branch, Fisheries and Oceans Canada, St. John's, NL, Canada A1C 5X1
}

Correspondence should be addressed to Cynthia A. Coles; ccoles@mun.ca

Received 29 August 2014; Revised 25 November 2014; Accepted 26 November 2014; Published 18 December 2014

Academic Editor: Teodoro M. Miano

Copyright ( 2014 Cynthia A. Coles et al. This is an open access article distributed under the Creative Commons Attribution License, which permits unrestricted use, distribution, and reproduction in any medium, provided the original work is properly cited.

\begin{abstract}
Concentrations of $\mathrm{Cu}, \mathrm{Cr}$, and As in soils surrounding 26 Douglas Fir Chromated Copper Arsenate (CCA) treated utility poles and in rainwater runoff from a new CCA treated utility pole segment $(\log )$ suspended outside in a cylinder were studied. The age of the utility poles, distances from the poles, rainfall amounts, and characteristics of soil samples including cation exchange capacity (CEC), $\mathrm{pH}$, and total organic carbon (TOC) were considered. Heavier rainfall, damp conditions, and more weathered poles contributed to the greatest leaching of $\mathrm{Cu}, \mathrm{Cr}$, and As. The maximum measured soil concentrations of $\mathrm{Cu}, \mathrm{Cr}$, and $\mathrm{As}$ were $37.5,65.5$, and $38.9 \mathrm{mmol} / \mathrm{kg}$ and maximum $\mathrm{Cu}, \mathrm{Cr}$, and As concentrations in rainwater run-off were $14,77.7 \mathrm{and} 55.8 \mu \mathrm{mol} / \mathrm{L}$. Metal concentrations decreased with distance from the poles and, except at one utility pole location, Cu was the most leached of the three elements. The As appeared to have greater mobility in the soil than the $\mathrm{Cr}$. Along the transmission line nearest the coast and from which the greatest amount of samples was collected, soil CEC and TOC values were the highest and the CEC and TOC were directly and strongly correlated.
\end{abstract}

\section{Introduction}

Chromated Copper Arsenate (CCA) has been employed extensively since the 1930 s as a wood preservative [1-3] to protect structures such as utility poles, fence posts, backyard decks, playground equipment, and marine structures from fungal and bacterial attack. However, recognition of the hazards of CCA has led to some reduction in its use as, for example, its banning in the residential areas in the U.S. $[4,5]$. There is also the problem of retiring CCA-treated structures that are currently in use [6]. CCA-treated wood can have a service life of up to 50 years and its use in post-consumer products (such as landscape mulch), determined to be $0.9 \%$ in the UK in 2001, could reach $12.3 \%$ in the UK in $2061[4,7]$. In South Africa, CCA is still commonly used and local food vendors in Cape Town are even cooking food over fires fueled with CCA-treated wood [1].

Slightly different formulations of CCA (CCA-A, CCA$\mathrm{B}$, and (CA-C) exist but CCA-C containing $18.5 \% \mathrm{CuO}$ (copper oxide), $47.5 \% \mathrm{CrO}_{3}$ (chromium oxide or anhydrous chromic acid), and $34 \% \mathrm{As}_{2} \mathrm{O}_{5}$ (arsenic pentoxide) is the most common [8-10]. The role of the $\mathrm{Cu}$ and As is to deter fungi and insects, respectively, and the $\mathrm{Cr}$ is intended to act as a fixative $[11,12]$. During CCA application, $\mathrm{Cr}(\mathrm{VI})$ is reduced to $\mathrm{Cr}$ (III) and the final products may include $\mathrm{Cr}$ (III) arsenate$\left(\mathrm{CrAsO}_{4^{-}}\right)$lignin complexes, chromate- $\left(\mathrm{CrO}_{4}{ }^{2-}-\right)$ lignin and cellulose complexes, $\mathrm{Cu}$ (II-) wood carboxylate complexes, and $\mathrm{Cr}$ (III) hydroxide $[10,13,14]$.

Local climate, leaching media, wood properties, and wood treatment techniques affect leaching of CCA from treated wood [14, and references therein] often as $\mathrm{Cu}$ or $\mathrm{Cr}$ arsenates and inorganic or organometallic complexes [11]. Leaching of $\mathrm{Cu}, \mathrm{Cr}$, and As may also be greater from wood that has been weathered [7]. Although CCA wood waste has been disposed of in approved landfills, preference is moving towards management options which include complete removal of CCA and its products from wood waste before 
disposal, both to address the shortage of landfill space and to reassure the public [15].

$\mathrm{Cu}$ (II) bonds with soil organic matter and is toxic to aquatic organisms and generally toxic above trace levels $[4,16]$. Organic matter and inorganic agents such as $\mathrm{Fe}$ can reduce $\mathrm{Cr}$ (VI) to the less toxic Cr (III) which forms complexes that are more stable and more retained by soils [17] though $\mathrm{Cr}$ speciation will also be influenced by the Eh$\mathrm{pH}$ conditions in soils [18]. Of great concern is As because of exposure effects in humans [19]. Arsenate (V) and arsenite (III) are the most common forms in soils [20] with As (III) being the more toxic and abundant [14]. Both As and $\mathrm{Cr}$ are known human carcinogens [4].

A study of $6 \mathrm{CCA} /$ polyethylene glycol (PEG) treated utility poles and found $23.0 \pm 10.7 \mathrm{mmol} / \mathrm{kg}$ of $\mathrm{Cu}, 5.52 \pm$ $0.62 \mathrm{mmol} / \mathrm{kg}$ of Cr , and $5.47 \pm 2.00 \mathrm{mmol} / \mathrm{kg}$ of As in adjacent soils [6]. A study of CCA treated fence posts reported a maximum soil concentration of $10.1 \mathrm{mmol} / \mathrm{kg}$ of As [19].

One objective of this study was to gain a better appreciation for the amount of leaching of $\mathrm{Cu}, \mathrm{Cr}$, and As that could occur from CCA treated utility poles and how the soil could be impacted by this leaching. The field study and measurements of leaching of $\mathrm{Cu}, \mathrm{Cr}$, and As from a freshly treated wooden log suspended outside in a cylinder provided some of these answers. For the water and soil samples, efforts were made to determine the effects of temperature, rainfall, and/or pole age on leaching of the metals. Another objective was to understand the nature of the soil environment where the field tests were conducted and to observe what effects, if any, the soil might have on the leaching of the metals. For this purpose soil characteristics such as the $\mathrm{pH}$, cation exchange capacity (CEC), and total organic carbon (TOC) of the soil samples were measured.

\section{Materials and Methods}

2.1. Site Description. Soil samples were collected from around utility poles along transmission lines (TLs 227, 259, and 225) in western Newfoundland. Transmission lines 227 and 259 run north out of Berry Hill approximately 30 and $60 \mathrm{~m}$ east, respectively, of the Northern Peninsula Highway, that borders the Gulf of St Lawrence and goes north as far as Peter's Barron outside Daniel's Harbour. Sampling along TLs 227 and 259 was only undertaken within Gros Morne National Park and the general area is illustrated in Figure 1(a). Transmission line 225 is a $2.4 \mathrm{~km}$ line running out of the Town of Deer Lake and bordering the northern edge of the lake of the same name, as outlined in Figure 1(a) and detailed in Figure 1(b). All of the utility poles along each transmission line were of the same age but each TL was of a different age.

Soil samples around 26 CCA treated utility poles were collected. Eighteen poles were from the Gros Morne National Park area, 14 of which were on TL 227 and 4 from TL 259. The remaining 8 utility poles were part of TL 225 near Deer Lake. The 26 poles were from 24 different sites because 1 site contained three poles. Soil sample locations were selected according to criteria proposed by the Electric Power Research Institute [21] for penta and creosote treated poles. All the poles were Douglas fir (Pseudotsuga menziesii), of known age, were from readily accessible areas having variable soil properties, were far from industrial areas, had not been exposed to pesticides or other contamination, were at least $1.80 \mathrm{~m}$ away from a roadway, and were situated in a clearing of at least $1.80 \mathrm{~m}$ in diameter.

To test for the decrease in the metal concentrations with distances from each of the 26 utility poles a least squares linear regression analysis was conducted on the samples.

To compare the effects of rainfall amounts for each metal and among the three TLs at the distance of $0 \mathrm{~cm}$, an unbalanced analysis of variance (ANOVA) (with Excel 2010) was conducted on these samples. Following the ANOVA, Tukey's procedure was employed to determine which TLs had significantly different population means.

To investigate correlations among the soil properties (TOC, $\mathrm{CEC}$, and $\mathrm{pH}$ ) for each $\mathrm{TL}$, linear regression analysis was employed.

2.2. Soil Sampling and Characterization. Soil samples were collected at distances of 0,30 , and $60 \mathrm{~cm}$ from the 26 poles and 3 background soil samples were collected at a distance of $7 \mathrm{~m}$ for a total of 81 soil samples.

Each sample was collected manually with a cleaned stainless steel spoon and placed in a new Ziploc bag that was sealed and refrigerated at $4^{\circ} \mathrm{C}$.

Soil samples were digested by US EPA method $3050 \mathrm{~B}$ [22] and stored in the refrigerator at $4^{\circ} \mathrm{C}$ until analyzed for $\mathrm{Cu}, \mathrm{Cr}$, and As. Analyses were carried out on a PerkinElmer SCIEX Elan 6100 inductively coupled plasma mass spectrometer (ICP MS) at Fisheries and Oceans Canada's Northwest Atlantic Fisheries Centre trace element lab in St. John's, Newfoundland, Canada. Quality control was monitored by the analyses of the National Institute of Standards and Technology (NIST) certified reference material 1463D. The results in ppb of repeated analyses $(n=4)$ of the NIST $1643 \mathrm{D}$ standard were $\mathrm{Cr} 18.4 \pm 2.5$, Cu $20.0 \pm 2.6$, and As $54.6 \pm$ 7.0. Certified ppb values for NIST $1643 \mathrm{D}$ were $\mathrm{Cr}$ $18.53 \pm 0.2$, Cu $20.5 \pm 3.8$, and As $56.2 \pm 0.73$. Detection limits for all three elements in dilute solutions were $<1.0 \mathrm{ppb}$. Rainwater samples were analyzed in the same lab and using the same equipment as the soil digests. A single NIST 1643 analyses was carried out during the analyses of the water samples for quality control purposes and the results in $\mathrm{ppb}$ were $\mathrm{Cr}$ 19.1, $\mathrm{Cu} 21.5$, and As 56.8.

Soil samples were analyzed for TOC by the modified Walkely-Black wet oxidation method [23]. The determination of the CEC of the soil samples was according to the $\mathrm{Ca}$ $(\mathrm{OAc})_{2}-\mathrm{CaCl}_{2}$ method [23]. Soil pH was determined with a 1:2 ratio of soil: $0.01 \mathrm{M} \mathrm{CaCl}_{2}$ [24]. Concentrations of $\mathrm{Cu}, \mathrm{Cr}$, and As and CEC values were measured in duplicate for $10 \%$ of the samples. All pH measurements and two thirds of TOC measurements for each sample were conducted in duplicate.

\subsection{Sampling of Runoff from a Freshly Treated Utility Pole} Segment. A $1.50 \mathrm{~m}$ long by $0.30 \mathrm{~m}$ diameter utility pole segment or log that was freshly treated with CCA was suspended vertically in a $2.40 \mathrm{~m}$ high by $1.20 \mathrm{~m}$ diameter plastic cylinder that was placed outside to be exposed to 


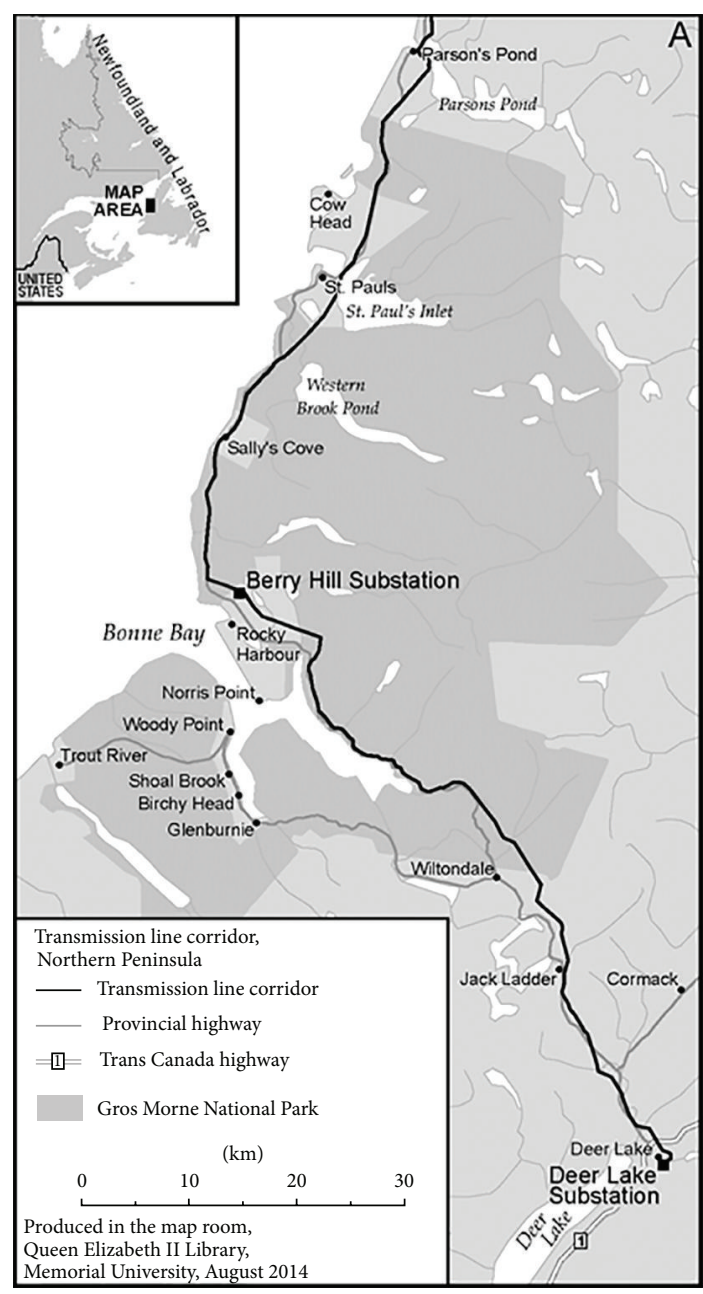

(a)

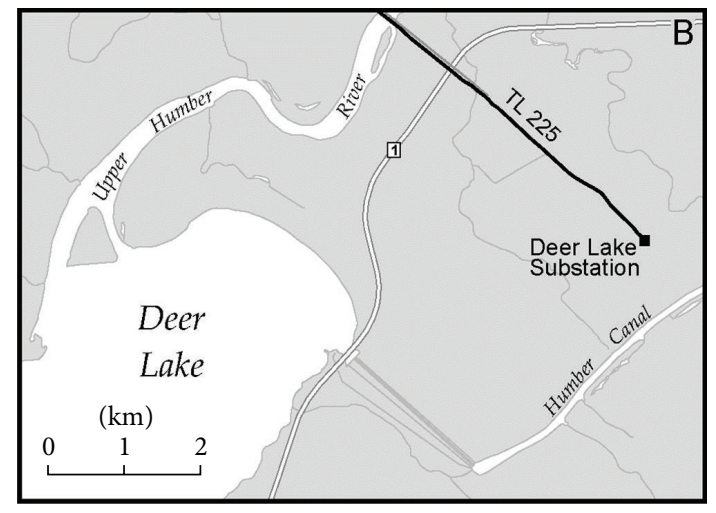

(b)

Figure 1: Areas of sampling along (a) TLs 227 and 259 and (b) TL 225.

the elements. The bottom of the cylinder was connected to an outlet for runoff collection. Sampling either took place after each rainfall event or after multiple days of rainfall, in which case the total rainfall since the previous sampling time was used. The sampling periods were September 5 to October 28, 2002, inclusive, April 27 to September 30, 2004, inclusive, and June 7 to July 25,2005 , inclusive, for which the rainfall amounts and maximum temperatures were recorded [25]. In 2003 when no samples were collected the log remained outside in the cylinder but the cylinder was covered with a board and the outlet was left open. The runoff samples and one background rainwater sample were acidified with $\mathrm{HNO}_{3}$ to less than $\mathrm{pH} 2$ and stored at room temperature until analysis.

\section{Results and Discussion}

\subsection{Runoff from the Suspended Log}

3.1.1. Trends in Leaching of Metals with Rainfall Amounts. To observe trends in leaching of $\mathrm{Cu}, \mathrm{Cr}$, and As from the pole segment with rainfall amount, water samples were considered separately in each of the three years so that pole age might be isolated as a factor, and only rainfall amounts $\geq 10 \mathrm{~mm}$ were used. The $10 \mathrm{~mm}$ cut-off was selected (1) to ensure rainfall amounts would be sufficiently measureable and (2) to give the $\log$ enough time to be well soaked in case this was required for leaching of the metals. The results from 2002, 2004, and 2005 are shown in Figures 2(a), 2(b), and 2(c), respectively.

In 2002 the greatest rainfall of $36.4 \mathrm{~mm}$ gave the greatest amount of leaching of $\mathrm{Cu}, \mathrm{Cr}$, and $\mathrm{As}$ from the log in that year. In 2004 the rainfall amounts of $22.8 \mathrm{~mm}, 30.6$, and $100.9 \mathrm{~mm}$ gave the three highest amounts of leached metals in that year. In 2005 the maximum rainfall of $42.6 \mathrm{~mm}$ produced the most leaching of metals from the log in that year.

The concentrations of leached $\mathrm{Cu}, \mathrm{Cr}$, and As were similar in 2002 and 2005 (Figures 2(a) and 2(c)). However, one difference was that in $2002 \mathrm{Cu}$ concentrations were greater than the two other elements and in 2005 As concentrations were less than the two other elements. Leaching of $\mathrm{Cu}$ was most pronounced in all years but especially in the first year. By the last year leaching of $\mathrm{Cr}$ became more similar to that of $\mathrm{Cu}$. 
In 2004 there were 7 instances when concentrations of the leached elements exceeded maximum amounts in 2002 and 2005 and the three events that showed the greatest leaching are examined and discussed in chronological order. These events were on August 31, September 5, and September 20 as shown in Figure 2(b) and each of the rainfall amounts happened to represent multiple days of rain.

With the first event on August 31, 2004, there was a total rainfall of $30.6 \mathrm{~mm}$ (trace, $1.2 \mathrm{~mm}$, trace, $16.4 \mathrm{~mm}$, and $13.0 \mathrm{~mm}$ on August 27, 28, 29, 30, and 31) and concentrations of $\mathrm{Cu}, \mathrm{Cr}$, and As leached from the suspended log were 29.4, 13.6, and $8.87 \mu \mathrm{mol} / \mathrm{L}$, respectively. The previous sampling and emptying of the collection cylinder had been on Aug 26. Rainfall occurred every day from August 17 to 31 inclusive and totaled $58.6 \mathrm{~mm}$. Fifteen consecutive days of damp conditions culminated in the great amount of leached metals observed on August 31.

On September 5, 2004 (the second event), there was a rainfall amount of $22.8 \mathrm{~mm}$ (16.2 and $6.6 \mathrm{~mm}$ on September 4 and 5) and the concentrations of $\mathrm{Cu}, \mathrm{Cr}$, and As leached from the $\log$ were $149,77.7$, and $55.8 \mu \mathrm{mol} / \mathrm{L}$, respectively. However, this time there had been 20 consecutive days of rain from August 17 to September 5 inclusive giving a total rainfall of $83.6 \mathrm{~mm}$. The extended period of damp conditions prior to sampling may have enhanced the removal of the $\mathrm{Cu}, \mathrm{Cr}$, and As from the log.

On September 4 and 5 the maximum temperatures were only $11.9^{\circ} \mathrm{C}$ and $11.1^{\circ} \mathrm{C}$, following three weeks with an average maximum temperature of $19.5^{\circ} \mathrm{C}$. After the 20 days of warm, damp weather, contraction of the wood with cooler temperatures might have forced some long retained water to be expelled and this might have also contributed to the highest recorded concentrations of $\mathrm{Cu}, \mathrm{Cr}$, and As leached from the suspended log. Others have observed that $\mathrm{Cu}$ and As leached more as the temperature rose whereas $\mathrm{Cr}$ leached slightly less at $30^{\circ} \mathrm{C}[26]$.

On September 20, 2004 (the third event), there was a rainfall amount of $100.9 \mathrm{~mm}$ (trace, $2.3 \mathrm{~mm}, 0 \mathrm{~mm}, 0 \mathrm{~mm}$, trace, $6.4 \mathrm{~mm}, 62 \mathrm{~mm}$, and $30.2 \mathrm{~mm}$ on September 13, 14, 15, $16,17,18,19$, and 20). Concentrations of $\mathrm{Cu}, \mathrm{Cr}$, and As leached from the $\log$ were $60.8,46.2$, and $50.5 \mu \mathrm{mol} / \mathrm{L}$, respectively. The $98.6 \mathrm{~mm}$ of rain that fell on the 4 consecutive days prior to sampling was the greatest amount of precipitation observed for any of the sample measurements and this high rainfall amount could have been important. The previous sampling had been on September 12 or 8 days prior.

These three instances of the greatest leaching of $\mathrm{Cu}, \mathrm{Cr}$, and As might be attributed to the total rainfall amounts, the long damp periods preceding the sample measurements, and possibly a drop in temperature. Given that prolonged dampness appears to enhance the leaching and that acids have been employed intentionally to extract CCA from wood waste [15], damp, acidic landfill environments would create ideal conditions for leaching of CCA from wood waste in landfills.

In each of 2002, 2004, and 2005 when sampling was being conducted, the full or partial months when rainfall was the highest were September 5-30, 2002 (104.6 mm), September
2004 (205.7 mm), and June 7-30, 2005 (103 mm). In September 2004 the rainfall accumulation was approximately double the highest measured months in 2002 and 2005 and this likely contributed to two instances of the maximum leaching from the suspended log. From 1981 to 2010 the average precipitation in St. John's during September was $129.6 \mathrm{~mm}$ [27]. The rainfall accumulation in September 2004 was clearly exceptional.

From a total of 57 samples of runoff from the log, the average amounts of $\mathrm{Cu}, \mathrm{Cr}$, and As were 8.98, 5.30, and $3.88 \mu \mathrm{mol} / \mathrm{L}$, respectively. The one background rainwater sample contained $\mathrm{Cu}, \mathrm{Cr}$, and As concentrations of 1.134, 0.015 , and $0.002 \mu \mathrm{mol} / \mathrm{L}$, respectively. However, 5 of the 57 runoff samples contained less $\mathrm{Cu}$ than in the background water, with the lowest $\mathrm{Cu}$ concentration being $0.52 \mu \mathrm{mol} / \mathrm{L}$. There could have been small variations in the rainwater concentrations and for the purpose of this study these concentrations were taken to be negligible.

\subsubsection{Metal Concentrations in Runoff from the Log Compared} to Water Quality Guidelines. Annual average, maximum, and standard deviations of concentrations of $\mathrm{Cu}, \mathrm{Cr}$, and $\mathrm{As}$ measured in runoff from the suspended log are reported in Table 1 . Water quality guidelines for $\mathrm{Cu}, \mathrm{Cr}$, and As for the protection of drinking water, freshwater and marine life, and agricultural livestock and crops [28] are also included for comparison.

As with Figure 2, Table 1 is showing similar metal concentrations in the runoff in 2002 and 2005 and higher amounts in 2004. The guideline for $\mathrm{Cu}$ in drinking water is for aesthetic purposes as $\mathrm{Cu}$ is an essential nutrient (high $\mathrm{Cu}$ concentrations might cause a green coating to form on bathroom and kitchen fixtures). In each year the average $\mathrm{Cr}$ concentrations in the runoff were higher than permissible for drinking water.

The average As concentration in each year exceeded all of the permissible limits for water with one exception being the 2005 average which was below the permissible limit for irrigation water. It is well known that As can migrate to the groundwater and cause contamination. This has been especially true in Florida where pesticides containing As have been applied to golf courses and because of frequent irrigation, a porous underlying soil system, and a shallow groundwater table, the groundwater has become contaminated [29].

3.2. Characteristics of the Soil Samples. The averages and ranges of values of $\mathrm{pH}, \mathrm{CEC}$, and TOC determined for each TL and for each of the three distances from each utility pole, are presented in Table 2. Regression analysis revealed that the TOC and CEC values were significantly and positively correlated for TL 227 at 0,30 , and $60 \mathrm{~cm}$ and the linear trend lines for these correlations had $P$ values of $0.00152,0.00864$, and $6.56 \times 10^{-7}$, respectively, and $R^{2}$ values of $0.581,0.450$, and 0.882 , respectively. No such correlations were found for the less sampled TLs 225 and 259 and no significant correlations were found among the other soil properties.

The strong positive correlation between CEC and TOC may be explained by the fact that the soil organic matter 


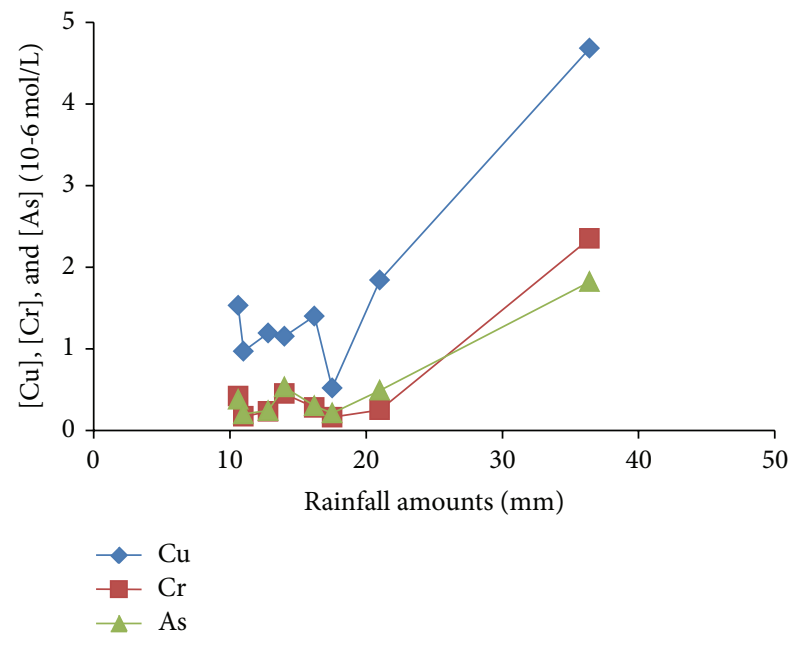

(a) 2002

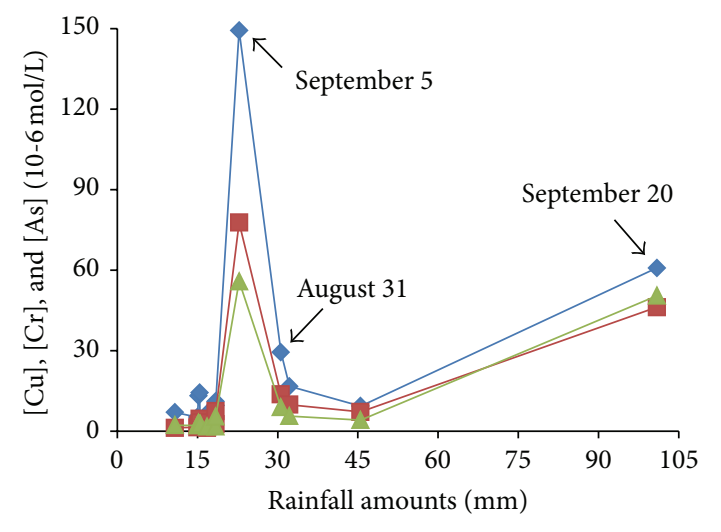

$\multimap \mathrm{Cu}$
$-\mathrm{Cr}$
$-\mathrm{As}$

(b) 2004

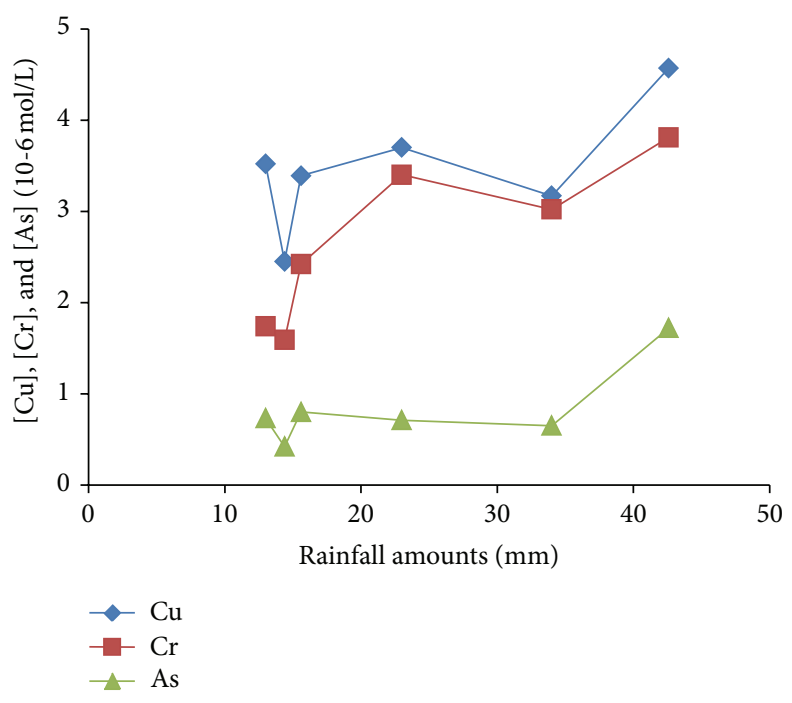

(c) 2005

FIGURE 2: Rainfall amount of $\geq 10 \mathrm{~mm}$ and corresponding leaching of $\mathrm{Cu}, \mathrm{Cr}$, and As from the suspended log in (a) 2002, (b) 2004, and (c) 2005.

TABLE 1: Average, maximum, and standard deviation (stdev) values of $\mathrm{Cu}, \mathrm{Cr}$, and As concentrations in runoff from the suspended log and water quality guidelines [28].

\begin{tabular}{|c|c|c|c|c|c|c|c|c|}
\hline & $\begin{array}{l}2002 \text { Average, } \\
\text { maximum, and } \\
\text { stdev (of 14) }\end{array}$ & $\begin{array}{l}2004 \text { Average, } \\
\text { maximum, and } \\
\text { stdev (of 33) }\end{array}$ & $\begin{array}{l}2005 \text { Average, } \\
\text { maximum, and } \\
\text { stdsev (of 11) }\end{array}$ & $\begin{array}{c}\text { Limit for } \\
\text { drinking water }\end{array}$ & $\begin{array}{l}\text { Limit for } \\
\text { fresh water }\end{array}$ & $\begin{array}{c}\text { Limit for } \\
\text { marine water }\end{array}$ & $\begin{array}{l}\text { Limit for } \\
\text { livestock }\end{array}$ & $\begin{array}{l}\text { Limit for } \\
\text { irrigation }\end{array}$ \\
\hline \multirow{3}{*}{$\begin{array}{l}\mathrm{Cu} \\
(\mu \mathrm{mol} / \mathrm{L})\end{array}$} & 3.85 & 12.8 & 3.26 & \multirow{3}{*}{$15.7^{1}$} & & & & \\
\hline & 33.4 & 149 & 5.17 & & & & & \\
\hline & 8.56 & 26.9 & 1.00 & & & & & \\
\hline \multirow{3}{*}{$\begin{array}{l}\mathrm{Cr} \\
(\mu \mathrm{mol} / \mathrm{L})\end{array}$} & 2.74 & 7.08 & 2.79 & \multirow{3}{*}{0.961} & & & & \\
\hline & 31.5 & 77.7 & 5.48 & & & & & \\
\hline & 8.31 & 15.0 & 1.23 & & & & & \\
\hline \multirow{3}{*}{$\begin{array}{l}\text { As } \\
(\mu \mathrm{mol} / \mathrm{L})\end{array}$} & 1.53 & 5.70 & 1.13 & \multirow{3}{*}{0.133} & \multirow{3}{*}{0.067} & \multirow{3}{*}{0.167} & \multirow{3}{*}{0.334} & \multirow{3}{*}{1.33} \\
\hline & 14.0 & 55.8 & 2.60 & & & & & \\
\hline & 3.63 & 12.4 & 0.625 & & & & & \\
\hline
\end{tabular}

\footnotetext{
${ }^{1}$ Aesthetic objective, [28].
} 
TABLE 2: Average and standard deviation values of $\mathrm{pH}, \mathrm{CEC}$, and TOC for soil samples collected along each transmission line.

\begin{tabular}{cccc}
\hline TL & $\begin{array}{c}\text { pH average, } \\
\text { stdev, and } \\
\text { range }\end{array}$ & $\begin{array}{c}\text { CEC average, stdev, } \\
\text { and range (meq/100 g) }\end{array}$ & $\begin{array}{c}\text { TOC average, } \\
\text { stdev, and } \\
\text { range (\%) }\end{array}$ \\
\hline \multirow{2}{*}{227} & 4.9 & 29.3 & 3.71 \\
& 0.789 & 19.2 & 2.94 \\
& $4.1-7.3$ & $0-71.3$ & $0-10.2$ \\
\hline \multirow{2}{*}{225} & 6.1 & 12.2 & 1.45 \\
& 1.05 & 4.71 & 0.889 \\
& $4.2-7.6$ & $5.5-23.3$ & $0-10.2$ \\
\hline \multirow{2}{*}{259} & 5.0 & 13.9 & 1.56 \\
& 0.870 & 7.30 & 1.20 \\
& $4.1-6.3$ & $5.7-21.5$ & $0.4-3.9$ \\
\hline
\end{tabular}

TABLE 3: Details related to the sampling of soils along the three TLs.

\begin{tabular}{cccccc}
\hline TL Age (y) & $\begin{array}{c}\text { Poles } \\
\text { sampled }\end{array}$ & Location & Comments & $\begin{array}{c}\text { Precipitation, } \\
\text { monthly average } \\
(\mathrm{mm})\end{array}$ \\
\hline 227 & 1 & 14 & Gros Morne & Coastal & 95.2 \\
225 & 2 & 8 & Deer Lake & Inland & 88.8 \\
259 & 13 & 4 & Gros Morne & Coastal & 102.5 \\
\hline
\end{tabular}

contains a large proportion of carboxyl groups that dissociate and contribute to negative charge and result in a high CEC [30]. It was determined by Zagury et al. [6] that organic soils had higher CEC values than clay soils and that an organic matter contribution to CEC would be greater than a clay contribution.

Table 2 is showing more similar pHs of soils along the parallel TLs 227 and 259, though soils along the more coastal TL 227 had double the organic matter content, indicating more organic enrichment of soils nearer the coast.

Most of the soil samples were slightly acidic in $\mathrm{pH}$ and about $40 \%$ had TOC contents in the range of 0 to $1 \%$. It has been found that leaching of $\mathrm{Cu}$ from CCA timber increased in more acidic soils [31] whereas [32] found the leaching of $\mathrm{Cu}$ increased in more alkaline soils. As was seen with the suspended log, heavy precipitation and damp conditions appeared to have a significant effect on the leaching of $\mathrm{Cu}, \mathrm{Cr}$, and As.

\subsection{Soil Sampling at 0, 30, and $60 \mathrm{~cm}$ Distances from the Utility} Poles and Precipitation Effects. Details related to the sampling of soils are summarized in Table 3 . The ages of the poles indicate how long they had been exposed to precipitation at the time that the sampling was undertaken in July 2002. The last column of the table is the estimated average monthly precipitation from the time that the pole was installed until the time that the samples were collected. The Deer Lake A station $\left(49^{\circ} 13^{\prime} \mathrm{N}, 57^{\circ} 24^{\prime} \mathrm{W}\right.$, and EL $\left.21.90 \mathrm{~m}\right)$ was used to determine the precipitation for TL 225. The station at Cow Head $\left(49^{\circ} 54^{\prime} 42 \mathrm{~N}, 57^{\circ} 47^{\prime} 20 \mathrm{~W}\right.$, EL $15.2 \mathrm{~m}$, Figure 1(a)), through which TL 227 runs, was used to determine the precipitation for TL 227 and parallel TL 259 [25].
TABLE 4: Mean and standard deviation (stdev) values and results of an unbalanced ANOVA of the $\mathrm{Cu}, \mathrm{Cr}$, and As concentrations at $0 \mathrm{~cm}$ from the utility poles of TLs 227, 225, and 259.

\begin{tabular}{lccc}
\hline \multirow{2}{*}{$\mathrm{TL}$} & $\begin{array}{c}\text { Mean and stdev } \\
{[\mathrm{Cu}](\mathrm{mmol} / \mathrm{kg})}\end{array}$ & $\begin{array}{c}\text { Mean and stdev } \\
{[\mathrm{Cr}](\mathrm{mmol} / \mathrm{kg})}\end{array}$ & $\begin{array}{c}\text { Mean and stdev } \\
{[\mathrm{As}]}\end{array}$ \\
\hline \multirow{2}{*}{227} & 10.8 & 3.57 & 4.12 \\
& 9.37 & 3.74 & 3.60 \\
\hline \multirow{2}{*}{225} & 4.11 & 1.55 & 1.20 \\
& 1.80 & 0.960 & 0.957 \\
\multirow{2}{*}{259} & 19.1 & 21.8 & 13.7 \\
& 10.7 & 29.3 & 16.9 \\
\hline \multirow{2}{*}{$P$ values } & 0.019292 & 0.014372 & 0.018510 \\
\hline
\end{tabular}

The results of the least squares linear regression analysis of soil samples with distance from the utility poles for $\mathrm{Cu}$, $\mathrm{Cr}$, and As concentrations are shown in Figures 3, 4, and 5 , respectively. These figures indicate trends of decreasing $\mathrm{Cu}, \mathrm{Cr}$, and As concentrations with distance from the poles since, for all but two metals on TL 259 for which only four poles were sampled, this trend is statistically significant. Usually both linear and exponential decreases in metal concentrations fit the data but in each case the line that gave the best fit or highest $R^{2}$ value is shown on the figure. Decreasing $\mathrm{Cu}, \mathrm{Cr}$, and As concentrations with distance from the poles was also reported by Zagury et al. and Hingston et al. $[6,14]$.

Figures 3, 4, and 5 show that the greatest scatter for each TL and for each metal is at the $0 \mathrm{~cm}$ distance and the trend in metal reduction with distance from the pole is most pronounced for $\mathrm{Cu}$.

The results of the ANOVA comparing the effects of rainfall amounts among the three TLs, along with the mean and standard deviation values for each TL at $0 \mathrm{~cm}$ (Table 4), indicate that at least two of the TLs are different from each other for each metal and show that for all three metals the average metal concentrations are highest along TL 259 (also apparent from Figures 3, 4, and 5) and lowest along TL 225. These relative metal concentrations can be seen to be in proportion to the average monthly precipitation amounts in Table 3.

The results of the pairwise comparison of the TLs using Tukey's procedure, required to confirm significantly dissimilar leaching of metals from the TLs, are presented in Table 5. The minimum differences in means or $T$-values between TLs compared to the actual differences in means confirm with 95\% confidence that TLs 225 and 259 are different for all metals (bolded fonts) and that TLs 227 and 259 are different for $\mathrm{Cr}$ and As (bolded fonts). The least dissimilar TLs were TLs 227 and 225. These results could be explained by combinations of pole age, average monthly rainfall, and excess CCA being leached out of the newest poles.

Ultraviolet exposure plays a major role in the weathering of CCA-treated wood and the leaching of $\mathrm{Cu}, \mathrm{Cr}$, and $\mathrm{As}$ and $[7,33$, and a reference therein] report that leaching is greater from weathered wood. Weathering by rain, wind, sun, salts, and temperature changes could assist in releasing the CCA components from the wood. Increasing pole age would 


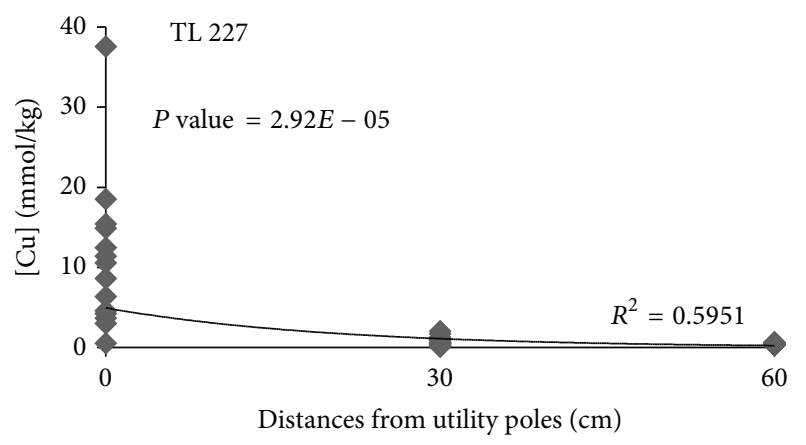

(a)

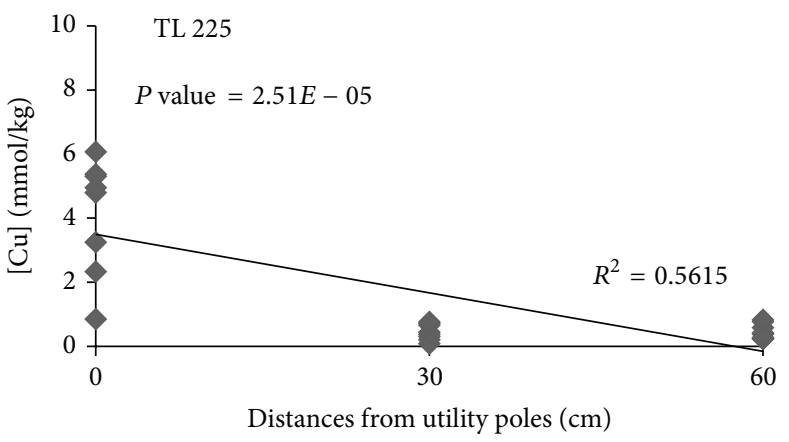

(b)

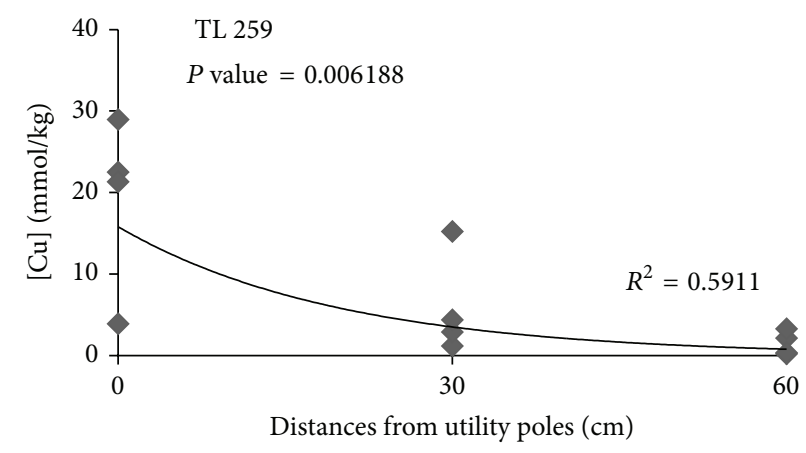

(c)

Figure 3: Concentrations of $\mathrm{Cu}$ at 0,30 , and $60 \mathrm{~cm}$ from TLs 227, 225, and 259 with $P$ values from the regression analysis and $R^{2}$ values for the trend line fit.

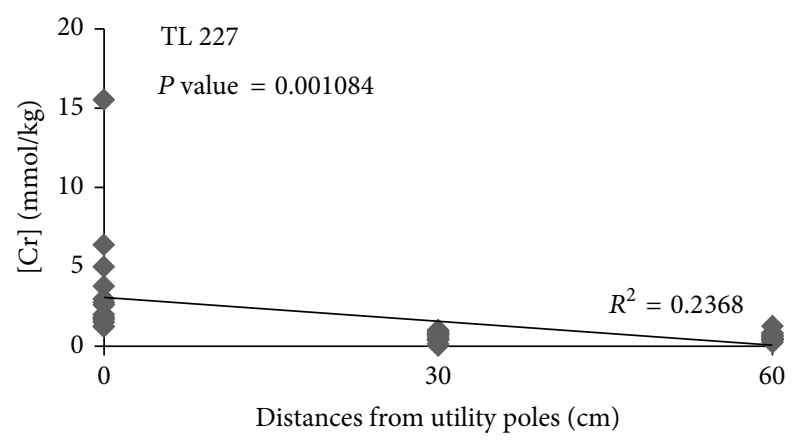

(a)

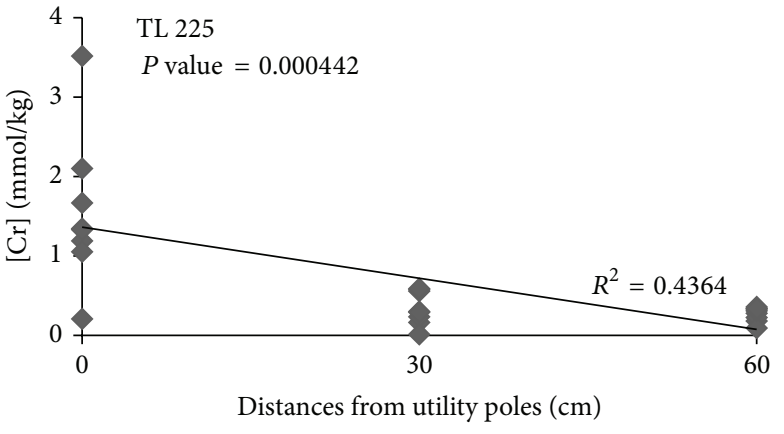

(b)

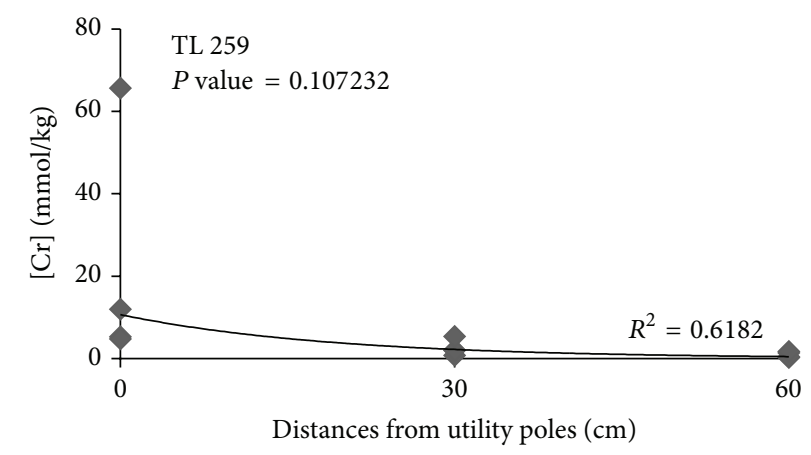

(c)

Figure 4: Concentrations of $\mathrm{Cr}$ at 0,30 , and $60 \mathrm{~cm}$ from TLs 227, 225, and 259 with $P$ values from the regression analysis and $R^{2}$ values for the trend line fit. 


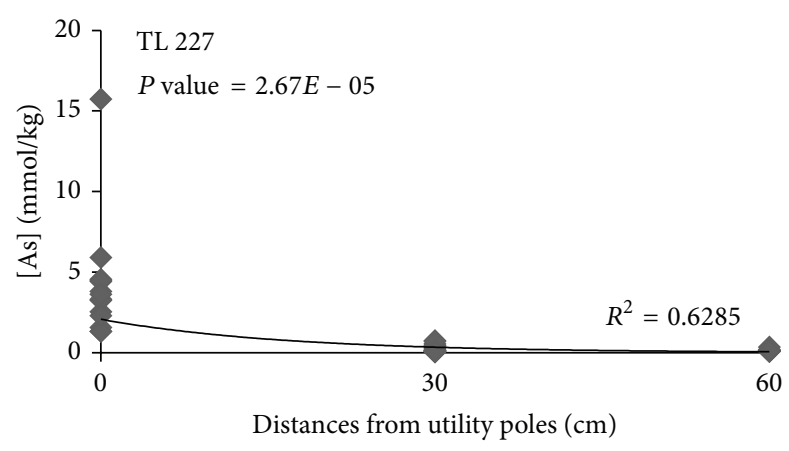

(a)

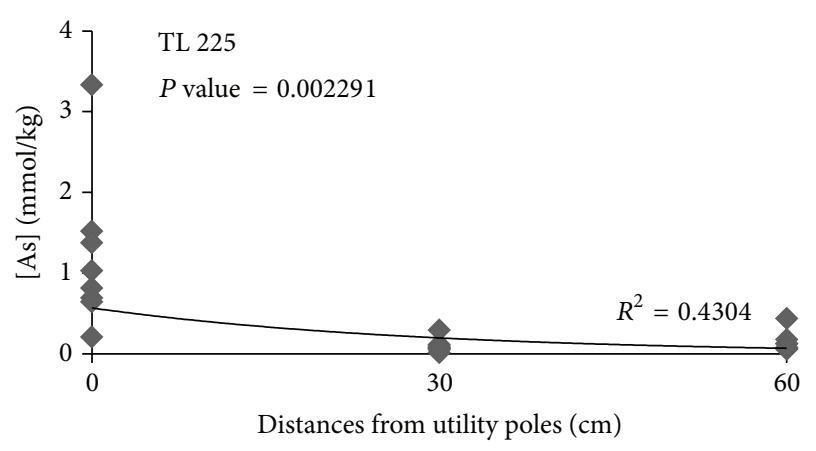

(b)

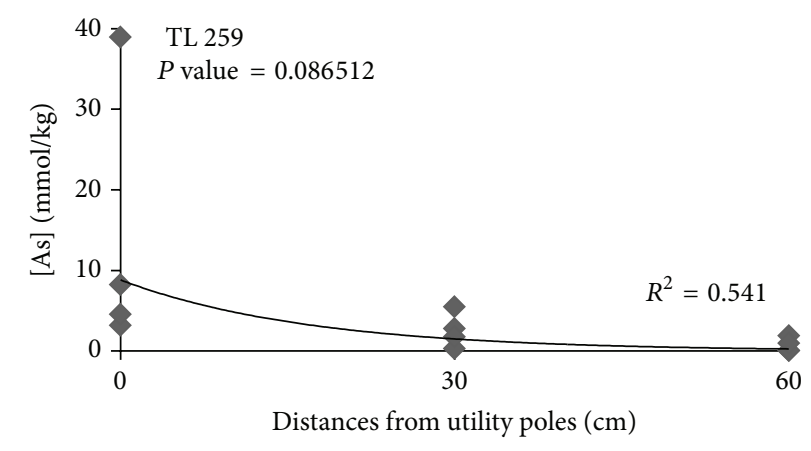

(c)

Figure 5: Concentrations of As at 0,30, and $60 \mathrm{~cm}$ from TLs 227, 225, and 259 with $P$ values from the regression analyses and $R^{2}$ values for the trend line fit.

TABLE 5: Results of pairwise comparison of TLs with Tukey's procedure show the minimum differences in means ( $T$-values) necessary for TLs to be significantly different (with $95 \%$ confidence) with shaded areas showing dissimilar pairs.

\begin{tabular}{lcccccc}
\hline \multirow{2}{*}{ TLs compared } & \multicolumn{2}{c}{$[\mathrm{Cu}](\mathrm{mmol} / \mathrm{kg})$} & \multicolumn{2}{c}{$[\mathrm{Cr}](\mathrm{mmol} / \mathrm{kg})$} & \multicolumn{2}{c}{$[\mathrm{As}](\mathrm{mmol} / \mathrm{kg})$} \\
& $T$-values & Actual & $T$-values & Actual & T-values & 6.14 \\
\hline $227 \& 225$ & 8.98 & 6.67 & 10.0 & 2.02 & $\mathbf{1 8 . 2}$ & 9.52 \\
$227 \& 259$ & 11.5 & 8.32 & 15.5 & $\mathbf{2 0 . 2}$ & 10.3 & $\mathbf{9 . 6 1}$ \\
$225 \& 259$ & 12.4 & $\mathbf{1 5 . 0}$ & 16.8 & $\mathbf{1 2 . 5}$ \\
\hline
\end{tabular}

normally increase the exposure of the pole to weathering. There may also be a "significant wash-off effect" with newly treated poles [4].

The least dissimilar and closest in age TLs were the 1-yearand 2-year-old TLs (227 and 225). The most dissimilar pair of TLs, 225 and 259, experienced the greatest difference in average monthly rainfall amounts $(13.7 \mathrm{~mm})$ in addition to having an age gap of 11 years. The reason TLs 227 and 259 were less dissimilar than TLs 225 and 259, despite the age gap of 12 years, was likely due to extra leaching from the 1-yearold poles and less difference in the average monthly rainfall amounts $(7.3 \mathrm{~mm})$. Rainfall amount was also important for leaching of metals from the suspended log.

With partitioning of metals between the soil and pore fluid phases, one portion of the metals is retained and another portion migrates, and to some extent metal retention by soils increases with metal concentration. More metals could have been able to accumulate in the soils of the 13-year-old poles
(TL 259). Using the mean metal concentrations in Table 4, the ratio of metals in the soils at 13 years compared to 1 year are $1.77(\mathrm{Cu}), 6.10(\mathrm{Cr})$, and $3.33(\mathrm{As})$ and compared to 2 years are $4.64(\mathrm{Cu}), 14.0(\mathrm{Cr})$, and $11.4(\mathrm{As})$. More $\mathrm{Cu}$ being removed early on from the suspended log could explain the more similar Cu removal at 1 and 13 years (Tables 4 and 5 ). The greatest relative accumulation of $\mathrm{Cr}$ in the soils by 13 years may be indicating that $\mathrm{Cr}$ was the least mobile. There was less As than $\mathrm{Cr}$ accumulation in soils by 13 years which could mean that As was more mobile than $\mathrm{Cr}$, something also noted by Zagury et al. and Stilwell and Gorney $[6,12]$.

Under flooding, anaerobic conditions (such as a torrential and prolonged rainfall that is causing the soil to become saturated), arsenate (V) is reduced to arsenite (III) and any As (V) bonded to the soil could be released as As (III) [34]. Such mobilization of As (III) could facilitate its downward migration (potentially to the groundwater) as long as the heavy rainfall persists. If reducing conditions are combined 
with lower $\mathrm{pH}$ as observed for the coastal soils along TLs 227 and 259, arsine gas, and dimethylarsine could also form and be released to the atmosphere [34].

The less mobile Cr (III) is likely to occur when organic matter and inorganic iron compounds are present in soils [17]. Anthropogenic $\mathrm{Cr}$ (VI) discharged to the environment is usually converted to $\mathrm{Cr}$ (III) which is the more commonly occurring in the environment [35]. The use of wood vinegar to extract $\mathrm{Cu}, \mathrm{Cr}$, and As from CCA-treated wood waste was the least successful for $\mathrm{Cr}$ [15]. Thus, there is some body of literature that supports that As could be more mobile in the environment than $\mathrm{Cr}$.

When anthropogenic $\mathrm{Cu}$ is introduced to surface soils it has a strong affinity for organic matter and clays [36]. Even if released by surface soils it can become bonded to any reactive fine particulate soils, including organic and clay soils at depth and is not usually mobile [36]. Of the three metals, the leaching of $\mathrm{Cu}$ may be of least concern because it tends to remain bonded to the soil.

Comparing the proportions of $\mathrm{Cu}, \mathrm{Cr}$, and As in the CCA$\mathrm{C}\left(18.5 \% \mathrm{CuO}, 47.5 \% \mathrm{CrO}_{3}\right.$, and $\left.34 \% \mathrm{As}_{2} \mathrm{O}_{5}\right)$ with the soil samples in this study (Table 4) leads to the conclusion that $\mathrm{Cu}$ was the most readily removed from the poles throughout the time periods under consideration. Another study of metal leaching from CCA treated utility poles [6] found that $\mathrm{Cu}$ concentrations in the soil samples were always higher than the $\mathrm{Cr}$ and As concentrations and [36] suggest $\mathrm{Cu}$ is not mobilized in soils that contain fine reactive soil particles such as organic matter or clays. For 25 of the 26 poles in this study $\mathrm{Cu}$ concentrations were the highest but this is not apparent for the 13-year-old poles along TL 259 (Table 4 and Figure 4) because at $0 \mathrm{~cm}$ from one pole ( $\mathrm{P}$ 101) the $\mathrm{Cr}$ concentration was the highest and was so high that it changed the observed trend in the average values. If this particular utility pole was of low quality wood so that it was more prone to becoming weathered or if it was installed in an especially exposed location where it was more susceptible to weathering, this might explain the high levels of leaching of all metals. Among the three metals, wood vinegar most successfully removed $\mathrm{Cu}$ from the CCA-treated wood waste [15]. Though $\mathrm{Cu}$ could be the most readily removed from the utility poles, it may be well retained by the soil.

3.4. Maximum $\mathrm{Cu}, \mathrm{Cr}$, and As Concentrations in Soils. Table 6 shows the most extreme cases of leaching of $\mathrm{Cu}, \mathrm{Cr}$, and As from the utility poles. Only pole P101 exhibited greater leaching of $\mathrm{Cr}$ than $\mathrm{Cu}$. Although the $\mathrm{Cr}$ concentration here was unexpectedly high, of all the soil samples measured at 30 and $60 \mathrm{~cm}$, the highest $\mathrm{Cr}$ concentrations at these two distances were also observed at this pole and so this number in Table 6 is reasonable.

Although sampling was only conducted at 4 poles along TL 259, it is noteworthy that soil samples surrounding 3 of the 4 poles contained some of the highest metal concentrations. This appears to be evidence of greater leaching from the utility poles that were older, more exposed to rainfall, and more weathered as also supported by Mercer and Frostick [7].
TABle 6: Extreme Cu, Cr, and As concentrations in soils near 1-, 2-, and 13-year-old poles.

\begin{tabular}{lccccc}
\hline $\begin{array}{l}\text { Approximate } \\
\text { pole age (years) }\end{array}$ & TL & Pole & $\begin{array}{c}\mathrm{Cu} \\
(\mathrm{mmol} / \mathrm{kg})\end{array}$ & $\begin{array}{c}\mathrm{Cr} \\
(\mathrm{mmol} / \mathrm{kg})\end{array}$ & $\begin{array}{c}\mathrm{As} \\
(\mathrm{mmol} / \mathrm{kg})\end{array}$ \\
\hline 1 & 227 & P1-8 & 37.5 & 15.5 & 15.7 \\
\hline 2 & 225 & P19L (N) & 17.3 & 6.12 & 2.48 \\
\hline \multirow{3}{*}{13} & \multirow{2}{*}{259} & P121 & 22.4 & 5.19 & 3.19 \\
& & P87 & 21.3 & 11.8 & 8.25 \\
& & P101 & 28.9 & 65.5 & 38.9 \\
\hline
\end{tabular}

\subsection{Soil Sample Measurements at All Distances and Compared} to Guidelines. Table 7 contains the average, standard deviation, and maximum values of metal concentrations at 0,30 , and $60 \mathrm{~cm}$ from all of the utility poles and at $7 \mathrm{~m}$ from three of the utility poles. The metal concentrations at $7 \mathrm{~m}$ were taken to approximate the natural background concentrations of the $\mathrm{Cu}, \mathrm{Cr}$, and As in soils. For all of the samples collected at 0 , 30 , and $60 \mathrm{~cm}$, seven of the nine highest metal concentrations were associated with pole P 101.

Arsenic is of great concern because of its known toxicity and the average As concentrations at $0 \mathrm{~cm}, 30 \mathrm{~cm}, 60 \mathrm{~cm}$, and $7 \mathrm{~m}$ all exceeded the permissible limit in soils. The highest As soil concentration measured was 2,431 times the permissible level. Soil concentrations of As in Newfoundland and Labrador are typically high and often above the guidelines. Average $\mathrm{Cu}$ concentrations at 0 and $30 \mathrm{~cm}$ exceeded the permissible limit for $\mathrm{Cu}$ in agricultural and residential soils and the average $\mathrm{Cr}$ concentration at $0 \mathrm{~cm}$ also exceeded the limits for $\mathrm{Cr}$ in soil.

\section{Conclusion}

With regard to runoff from the suspended log, $\mathrm{Cu}$ leached the most in the first year, and in the final (fourth) year the $\mathrm{Cr}$ leached almost as much as the $\mathrm{Cu}$ and the As leached noticeably less than the two other metals. The wettest month in 2004 saw $205.7 \mathrm{~mm}$ of rain, it compared with the 29 year average for that month of $129.6 \mathrm{~mm}$, it was almost twice as wet as other months during which rainfall runoff samples were collected, and it was associated with the two highest incidents of total leaching of metals from the log. Heavier rainfalls and longer durations of dampness preceding sample measurements appeared to increase the metals in the runoff. It is also possible that some contraction of the wood when warm temperatures turned cold may have squeezed more metals out of the log.

With regards to the water quality guidelines, the greatest exceedances were for As in the rainwater runoff. The average As concentration was greater than all the permissible water limits except for irrigation water and only in 2005 and exceeded by approximately 8 to 42 times the drinking water guideline limits. The average $\mathrm{Cr}$ concentrations in the rainwater runoff were approximately 3 to 7 times greater than the drinking water guideline limits while the average $\mathrm{Cu}$ concentrations in the rainwater runoff were all less than the drinking water guideline limits. 
TABLE 7: Average, standard deviation, and maximum values of all $\mathrm{Cu}, \mathrm{Cr}$, and As concentrations in soils at different distances from the poles compared with permissible soil concentrations.

\begin{tabular}{|c|c|c|c|c|c|c|}
\hline \multicolumn{5}{|c|}{$\begin{array}{c}\text { Average, standard deviation, and maximum values of metal concentrations of all } \\
\text { soil samples }(\mathrm{mmol} / \mathrm{kg})\end{array}$} & \multicolumn{2}{|c|}{ Permitted soil concentrations $[25,28](\mathrm{mmol} / \mathrm{kg})$} \\
\hline $\begin{array}{l}\text { Distance from } \\
\text { poles }\end{array}$ & $0 \mathrm{~cm}$ & $30 \mathrm{~cm}$ & $60 \mathrm{~cm}$ & $7 \mathrm{~m}$ & Agricultural, residential & Commercial, industria \\
\hline \multirow{3}{*}{$\mathrm{Cu}$} & 9.52 & 1.23 & 0.543 & 0.287 & \multirow{3}{*}{0.991} & \multirow{3}{*}{1.43} \\
\hline & 8.34 & 2.52 & 0.595 & 0.102 & & \\
\hline & 37.5 & $15.2^{1}$ & $3.20^{1}$ & 0.386 & & \\
\hline \multirow{3}{*}{$\mathrm{Cr}$} & 5.15 & 0.673 & 0.46 & 0.339 & \multirow{3}{*}{1.23} & \multirow{3}{*}{1.67} \\
\hline & 10.8 & 0.879 & 0.340 & 0.237 & & \\
\hline & $65.5^{1}$ & $5.24^{1}$ & $1.62^{1}$ & 0.484 & & \\
\hline \multirow{3}{*}{ As } & 4.22 & 0.459 & 0.183 & 0.126 & \multirow{3}{*}{0.016} & \multirow{3}{*}{0.016} \\
\hline & 6.57 & 1.00 & 0.337 & 0.173 & & \\
\hline & $38.9^{1}$ & $5.51^{1}$ & 1.92 & 0.323 & & \\
\hline
\end{tabular}

${ }^{1}$ Pole P 101 along TL 259 where most of the highest concentrations were detected.

With regards to the soil samples, there was a significant trend in decreasing metal concentration with distance from the utility poles and the greatest scatter in metal concentrations occurred at the $0 \mathrm{~cm}$ distance. TL 259 soil samples at $0 \mathrm{~cm}$ from the utility poles contained the highest metal concentrations and these poles were the most weathered because they were the oldest and had been exposed to the highest cumulative rainfall. TL 227 soil samples at $0 \mathrm{~cm}$ contained the second highest metal concentrations which may have been a result of a "wash-off" effect from the new poles. TL 225 soil samples had the lowest metal concentrations and these poles were exposed to the lowest average monthly precipitation.

With regards to the soil concentrations of the three metals, $\mathrm{Cu}$ was normally the most leached into the soil, and though the average $\mathrm{Cu}$ concentrations exceeded soil quality guideline limits at $0 \mathrm{~cm}$ and residential/agricultural guideline limits at $0 \mathrm{~cm}$ and $30 \mathrm{~cm}$, it may have been of least concern as it tends to be more retained by the soil (or less mobile within the soil). Soil As was the most critical because the average soil concentrations of As at all distances from the poles exceeded the acceptable allowable concentrations and As appeared to be the most mobile in the soil as well. There could be cause for concern that As could leach from CCA treated timber, migrate to groundwater, and reach wells or ponds, especially if the underlying soil is porous. Soil $\mathrm{Cr}$ only exceeded the acceptable allowable concentrations at the $0 \mathrm{~cm}$ distance and appeared to be less mobile than As so of less concern than As.

\section{Conflict of Interests}

The authors declare that there is no conflict of interests regarding the publication of this paper.

\section{Acknowledgments}

The authors are grateful to the Department of Fisheries and Oceans for providing their ICP-MS to use, the laboratory personnel in the Faculty of Engineering and Applied Science at Memorial University of Newfoundland (MUN), and Ms. Linda Windsor in the Chemistry Department at MUN. The authors thank the MUN Faculty of Engineering and Applied Science and the VP Research for their financial support. Mr. Terry Gardiner, Manager of Transmission and Distribution Engineering at Nalco, is much appreciated for the details he was able to provide on the TLs. The authors also gratefully acknowledge the Map Room of the Queen Elizabeth II Library at MUN where the maps were prepared.

\section{References}

[1] S. Naidoo, A. Africa, and M. A. Dalvie, "Exposure to CCAtreated wood amongst food caterers and residents in informal areas of Cape Town," South African Journal of Science, vol. 109, no. 7-8, pp. 1-7, 2013.

[2] P. S. Nico, S. E. Fendorf, Y. W. Lowney, S. E. Holm, and M. V. Ruby, "Chemical structure of arsenic and chromium in CCA-treated wood: Implications of environmental weathering," Environmental Science and Technology, vol. 38, no. 19, pp. 52535260, 2004.

[3] A. W. C. Lee, G. Chen, and F. H. Tainter, "Comparative treatability of Moso bamboo and Southern pine with CCA preservative using a commercial schedule," Bioresource Technology, vol. 77, no. 1, pp. 87-88, 2001.

[4] A. R. Hasan, L. Hu, H. M. Solo-Gabriele, L. Fieber, Y. Cai, and T. G. Townsend, "Field-scale leaching of arsenic, chromium and copper from weathered treated wood," Environmental Pollution, vol. 158, no. 5, pp. 1479-1486, 2010.

[5] United States Environmental Protection Agency, "Pesticides: Regulating Pesticides," 2011, http://www.epa.gov/oppad001/reregistration/cca.

[6] G. Zagury, R. Samson, and L. Deschênes, "Occurrence of metals in soil and ground water near chromated copper arsenatetreated utility poles," Journal of Environmental Quality, vol. 32, no. 2, pp. 507-514, 2003.

[7] T. G. Mercer and L. E. Frostick, "Leaching characteristics of CCA-treated wood waste: a UK study," Science of the Total Environment, vol. 427-428, pp. 165-174, 2012.

[8] W. J. Baldwin, E. A. Pasek, and P. D. Osborne, "Sediment toxicity study of CCA-treated marine piles," Forest Products Journal, vol. 4, no. 3, pp. 42-50, 1996.

[9] P. A. Cooper, Leaching of CCA: Is It a Problem? Environmental Considerations in the Manufacture, Use and Disposal of Pressure 
Treated Wood, Forest Products Society, Madison, Wis, USA, 1994.

[10] B. I. Khan, H. M. Solo-Gabriele, B. K. Dubey, T. G. Townsend, and Y. Cai, "Arsenic speciation of solvent-extracted leachate from new and weathered CCA-treated wood," Environmental Science and Technology, vol. 38, no. 17, pp. 4527-4534, 2004.

[11] S. Lebow, "Leaching of wood preservative components and their mobility in the environment. Summary of pertinent literature," General Technical Report FPL-GTR-93:36, Forest Products Laboratory, USDA Forest Service, Madison, Wis, USA, 1996.

[12] D. E. Stilwell and K. D. Gorny, "Contamination of soil with copper, chromium, and arsenic under decks built from pressure treated wood," Bulletin of Environmental Contamination and Toxicology, vol. 58, no. 1, pp. 22-29, 1997.

[13] D. C. Bull, "The chemistry of chromated copper arsenate II. Preservative-wood interactions," Wood Science and Technology, vol. 34, no. 6, pp. 459-466, 2001.

[14] J. A. Hingston, C. D. Collins, R. J. Murphy, and J. N. Lester, "Leaching of chromated copper arsenate wood preservatives: a review," Environmental Pollution, vol. 111, no. 1, pp. 53-66, 2001.

[15] Y.-S. Choi, B. J. Ahn, and G.-H. Kim, "Extraction of chromium, copper, and arsenic from CCA-treated wood by using wood vinegar," Bioresource Technology, vol. 120, pp. 328-331, 2012.

[16] T. Hung, P. J. Meng, and S. Wu, "Species of copper and zinc in sediments collected from the Antarctic Ocean and the Taiwan Erhjin Chi coastal area," Environmental Pollution, vol. 80, no. 3, pp. 223-230, 1993.

[17] H. Massara, C. N. Mulligan, and J. Hadjinicolaou, "Innovative treatment for chromium contaminated sites," in Proceedings of the 57th Canadian Geotechnical Conference, Montreal, Canada, 2004.

[18] T. Miano, V. D’Orazio, and C. Zaccone, “Trace elements and food safety," in PHEs, Environment and Human Health, C. Bini and J. Bech, Eds., Springer, 2014.

[19] D. R. Schwer III and D. H. McNear, "Chromated copper arsenate-treated fence posts in the agronomic landscape: soil properties controlling arsenic speciation and spatial distribution," Journal of Environmental Quality, vol. 40, no. 4, pp. 11721181, 2011.

[20] S. Wang and C. N. Mulligan, "Arsenic in Canada," in Proceedings of the 57th Canadian Geotechnical Conference, Québec, Canada, 2004.

[21] EPRI, "Preservatives in soils adjacent to in service utility poles in the United States," 1997.

[22] American Chemical Society, Reagent Chemicals, American Chemical Society Specifications, Washington, DC, USA, 7th edition, 1986.

[23] B. H. Sheldrick, Ed., Analytical Methods Manual, Land Resource Research Institute, Ottawa, Canada, 1984.

[24] W. P. Mortimer, The Environmental Persistence and Migration of Wood Pole Preservatives, Canadian Electrical Association, Montreal, Canada, 1991.

[25] "Historical Climate Data-Environment Canada-Advanced Search," http://climate.weather.gc.ca/advanceSearch/searchHistoricData_e.html.

[26] L. Waldron, P. Cooper, and T. Ung, "Modeling of wood preservative leaching in service," in Environmental Impacts of Preservative-Treated Wood Conference, pp. 81-97, Orlando, Fla, USA, 2004.

[27] Canada's National Climate Archive, http://climate.weather.gc .ca/climateData/dailydata_e.html?StationID $=6720$.
[28] Canadian Council of Ministers of the Environment, Canadian Environmental Quality Guidelines Summary Table, http:// www.ccme.ca/publications/ceqg_rcqe.html.

[29] T. J. Whitmore, M. A. Riedinger-Whitmore, J. M. Smoak, K. V. Kolasa, E. A. Goddard, and R. Bindler, "Arsenic contamination of lake sediments in Florida: evidence of herbicide mobility from watershed soils," Journal of Paleolimnology, vol. 40, no. 3, pp. 869-884, 2008.

[30] F. J. Stevenson, Humus Chemistry: Genesis, Composition, Reactions, John Wiley and Sons, New York, NY, USA, 1994.

[31] P. A. Cooper, "Leaching of CCA from treated wood: pH effects," Forest Products Journal, vol. 41, no. 1, pp. 30-32, 1991.

[32] P. L. Carey, R. G. Mclaren, and J. A. Adams, "Sorption of cupric, dichromate and arsenate ions in some New Zealand soils," Water, Air, and Soil Pollution, vol. 87, no. 1-4, pp. 189-203, 1996.

[33] R. S. Williams, S. Lebow, and P. Lebow, "Effect of simulated rainfall and weathering on release of preservative elements from CCA treated wood," Environmental Science \& Technology, vol. 37, no. 18, pp. 4077-4082, 2003.

[34] A. A. Duker, E. J. M. Carranza, and M. Hale, "Arsenic geochemistry and health," Environment International, vol. 31, no. 5, pp. 631-641, 2005.

[35] J. Harte, C. Holden, R. Schneider, and C. Shirley, Toxics A to Z: A Guide to Everyday Pollution Hazards, University of California Press, 1991.

[36] R. N. Yong, C. N. Mulligan, and M. Fukue, Sustainable Practices in Geoenvironmental Engineering, CRC Press, New York, NY, USA, 2nd edition, 2014. 

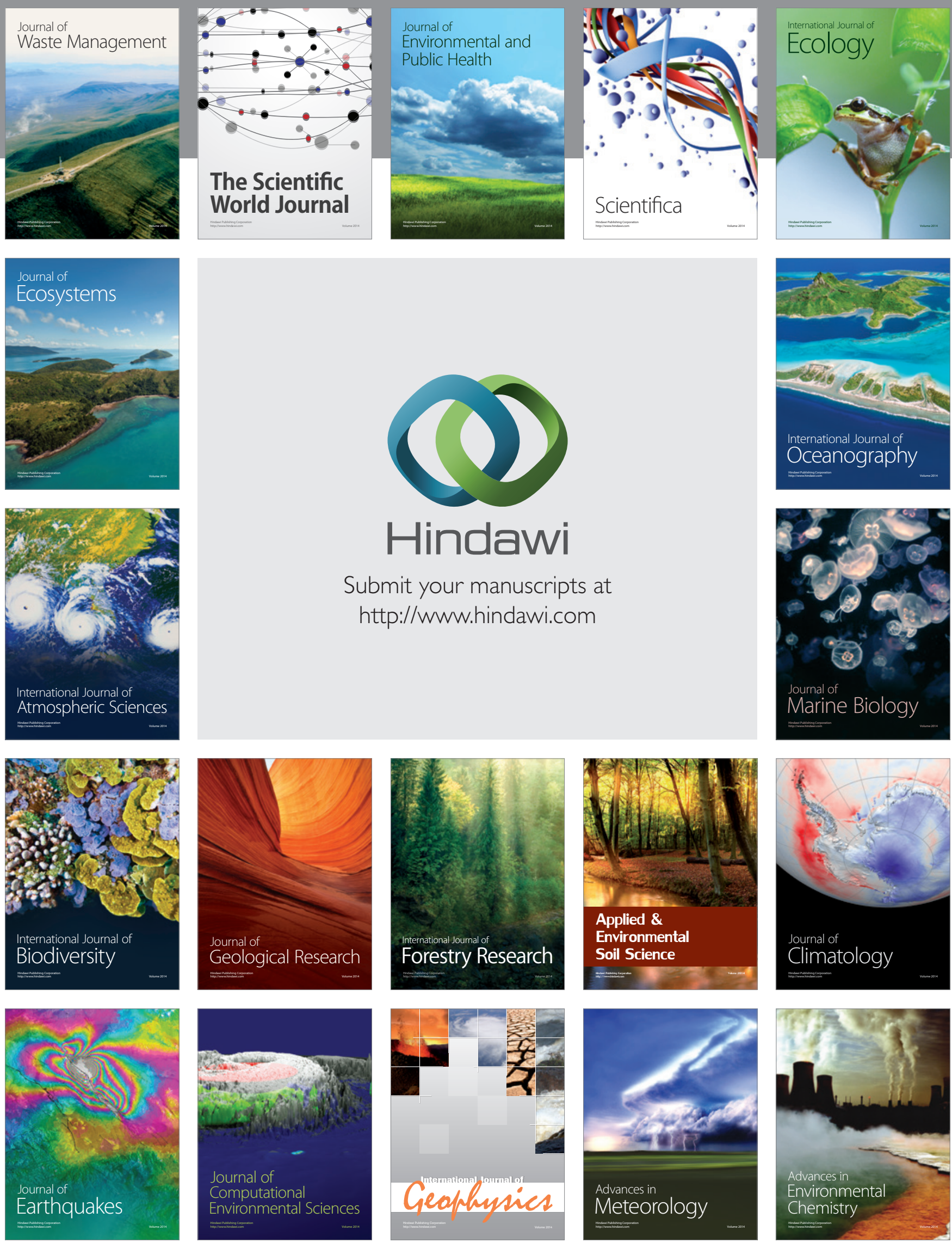